\title{
Obesity and Pancreatic Islet Hyperplasia in the Mongolian Gerbil*
}

\author{
L. Boquist \\ Institute of Pathology, University of Umeå, Umeå, Sweden \\ Received: February 20, 1972, accepted: April 28, 1972
}

\begin{abstract}
Summary. In a colony of Mongolian gerbils maintained on a standard laboratory diet, occasional obese animals were found. Obesity developed in animals of both sexes and was either transitory or permanent. The mean fasting blood glucose level in non-obese and obese gerbils was 83 and $105 \mathrm{mg} / 100 \mathrm{ml}$, respectively. Glucosuria and hyperglycemia were found only in a few obese animals, whereas the glucose tolerance was decreased in most obese gerbils. - The endocrine pancreas of the obese animals was morphologically either normal or more often hyperplastic, sometimes with the appearance of adenomatous islets. The $\beta$-cells possessed prominent Golgi complex and endoplasmic reticulum, and sparse granulation. Large, granule-poor cells and mitotic figures were seen in the islets. Degenerative changes occurred in the $\beta$-cells of diabetic animals. - It is suggested that the maintenance of the gerbils under laboratory conditions with free access to laboratory diet plays a major role in the development of obesity and that the endocrine pancreas of these animals has a good capacity for hyperplasia that often is sufficient to maintain normo-glycemia in obese animals, although the glucose tolerance is decreased.
\end{abstract}

Obésité et hyperplasie des îlots du pancréas chez la gerbille mongolienne

Résumé. Dans un élevage de gerbilles mongoliennes soumises à un régime standard de laboratoire ont été parfois trouvés des animaux obèses. L'obésité se développait chez les animaux des deux sexes et était tantôt transitoire, tantôt permanente. Le taux moyen de glucose du sang, à jeûn, chez les animaux non obèses et obèses était respectivement de 83 et $105 \mathrm{mg} / 100 \mathrm{ml}$. La gly. cosurie et l'hyperglycémie n'étaient trouvées que chez peu d'animaux obèses, tandis que la tolérance au glucose était réduite chez la plupart des animaux obèses. - Lo pancréas endocrine des animaux obèses était, morphologiquement, normal ou plus souvent hyperplasique avec parfois l'apparition d'îlots adénomateux. Les cellules $\beta$ possédaient un complexe de Golgi et un réticulum endoplasmique proéminents et une granulation faible. De grosses cellules pauvres en granules et des figures mitotiques se montraient dans les îlots. Des changements dégénératifs se produisaient dans les cellules $\beta$ des animaux diabétiques. - On suggère que le maintien des animaux dans les conditions de laboratoire avec libre accès au régime de laboratoire joue un rôle prédominant dans le développement de l'obésité et que le pancréas endocrine de ces animaux a une excellente capacité d'hyperplasie qui suffit souvent à maintenir la normoglycémie chez les animaux obèses, malgré la réduction de la tolérance au glucose.

Übergewicht und Hyperplasie der Pankreasinseln bei der mongolischen Rennmaus

Zusammenfassung. In einer Zucht von mongolischen Rennmäusen mit einer Laboratoriumsstandarddiät wurden gelegentlich übergewichtige Tiere gefunden. Die Übergewichtigkeit entwickelte sich bei beiden Geschlechtern und war entweder vorübergehend oder blieb für immer bestehen. Der durchschnittliche Nüchternblutzuckerspiegel bei nicht übergewichtigen und über. gewichtigen mongolischen Rennmäusen lag bei $83 \mathrm{bzw}$. $105 \mathrm{mg} / 100 \mathrm{ml}$. Glykosurie und Hyperglycämie wurden nur bei wenigen übergewichtigen Tieren gefunden, während die Glucosetoleranz bei den meisten übergewichtigen mongolischen Rennmäusen vermindert war. Das endokrine Pankreas von übergewichtigen Tieren war morphologisch entweder normal oder häufiger hyperplastisch, manchmal erschienen die Inseln adenomatös. Bei den $\beta$-Zellen waren die Golgi-Komplexe und das Endoplasmatische Reticulum vorspringend und es fanden sich schwache Granulationen. In den Inseln wurden große, an Granula arme Zellen und mitotische Figuren gesehen. In den $\beta$-Zellen diabetischer Tiere traten degenerative Veränderungen auf. - Es wird angenommen, daß das Halten von mongolischen Rennmäusen unter Laboratoriumsbedingungen mit freiem Zugang zu der Laboratoriumsnahrung eine größere Rolle bei der Entwicklung der Übergewichtigkeit spielt und daß das endokrine Pankreas dieser Tiere eine gute $\cdot$ Fähigkeit zur Hyperplasie besitzt, die oft ausreicht, um eine Normalglykämie bei übergewichtigen Tieren zu erhalten, obgleich die Glucosotoleranz abfällt.

Key words: Obesity, islet hyperplasia, Mongolian gerbil, pancreatic islets, $\beta$-cells, glucosuria, hyperglycemia, decreased glucose tolerance, hyperinsulinemia, electron microscopy, light microscopy, adenomatous islets, mitotic activity, glycogen infiltration, cellular inclusions.

\section{Introduction}

A colony of Mongolian gerbils has been bred in this laboratory since January 1968. Ultrastructural ex-

* Supported by grants from the Swedish Medical Research Council (Projects No. B71-12X-718-060 and B71-12X-718-07A) and the Swedish Diabetes Association.

* A preliminary report was given at the 7th Annual Meeting of the European Association for the Study of Diabetes, Suuthampton, September 15-17, 1971. aminations of their endocrine pancreas have disclosed an intimate association between vesicular particles and cilia [3], and nuclear inclusions [4]. Occasional gerbils in the colony have been found to develop obesity and islet hyperplasia with or without associated glucosuria, hyperglycemia and decreased glucose tolerance. Such alterations have not previously been reported in this species and since studies of animal syndromes might be of value for the understanding of human diabetes mellitus, this study was undertaken. 
Its main aim was to get further information about the association between obesity and the morphology and function of the pancreatic islets.

\section{Materials and Methods}

\section{Animals}

The colony consists of inbred Mongolian gerbils (Meriones ungiculatus) which are kept in standard laboratory animal cages under constant temperature $\left(22^{\circ} \mathrm{C}\right)$ and illumination ( 7 a.m. -8 p.m.). They have free access to food and water. The diet is of commercially available pelleted type that is obtained from A.B. Ewos, Södertälje, Sweden, and has the following composition (per cent): whey powder 5 ; expanded cereals 72 ; soybean oil meal 8; defatted fish meal 8 ; yeast 2 ; soybean oil 2; lime stone 1; vitamin concentrate 1; trace elements 1 . Average dry matter analysis : crude protein 20 ; crude fat 4 ; ash 3 ; (Ca $0.8 ; \mathrm{P} 0.6$; NaCl 0.6 ); fiber 3 ; nitrogen-free, extractable substances 68 . Water content: 8 . Trace elements added (per cent): Fe 0.0017; Cu 0.00017; Co 0.00017; Mn 0.0017 ; I $0.00006 ; \mathrm{Zn} 0.0125$. Vitamins added: vitamin A $360 \mathrm{IU}$; vitamin $\mathrm{D}_{3} 40 \mathrm{IU}$; vitamin $\mathrm{E} 4.2 \mathrm{mg}$; vitamin $B_{1} 0.15 \mathrm{mg}$; vitamin $B_{2} 0.30 \mathrm{mg}$; Ca-pantothenate $0.50 \mathrm{mg}$.

From the colony, animals were taken which developed obvious external signs of obesity, for weighing and morphological and functional studies. In all, 42 obese gerbils were investigated. 'Twenty non-obese, adult gerbils from the colony were used as controls. All animals were weighed once a week.

\section{Functional studies}

Glucose oxidase paper strips were used for urine glucose analysis. Blood was obtained by the orbital bleeding technic from either the right or left orbital venous plexus. Fasting blood glucose was determined by means of a glucose oxidase method (A.B. Kabi, Stockholm, Sweden). The glucose tolerance was investigated after intraperitoneal injection of $2 \mathrm{~g} / \mathrm{kg}$ body weight of glucose. Urinanalysis was carried out on all animals once a week, whereas the blood glucose and glucose tolerance was assayed in a varying number of animals every other week. The latter determinations were performed in each animal at least at two different occasions.

Serum insulin assays were performed in some (14 obese and 15 non-obese) gerbils by Dr. $\AA$. Lernmark, Department of Histology, Umeå, using the double antibody radioimmunological technic (mothod C) of Hales and Randle [13] with crystalline ox insulin (Vitrum A.B.e Stockholm, Sweden) as standard.

\section{Morphologic studies}

Pancreatic specimens for light microscopic examination were fixed in Bouin's fluid or 10 per cent formalin. 'The following stains were used: hematoxylin-eosin, van Gieson, Maske's aldehyde fuchsin, chrome alum hematoxylin, alkaline Congo red, Sudan black, and the staining procedures of Hellerström and Hellman, and Grimelius.

It was not the aim of the present study to perform an extensive quantitative determination of the islet volume. However, by rough estimation of light microscopic sections from the head, body and tail of the pancreas from obese and non-obese gerbils, differentiation could rather easily be made between animals with and those without islet hyperplasia.
For electron microscopic examinations pancreatic specimens were either fixed in 2.5 per cent glutaraldehyde in $0.34 \mathrm{M}$ Veronal acetate buffer adjusted to $p H \mathbf{7 . 4}$, followed by postfixation in 1 per cent osmium tetroxide in the same buffer, or directly in 1 per cent osmium tetroxide in the same buffer. After fixation the specimens were rinsed, dehydrated and embedded in Epon 812. The sections were cut on an Ultrotome III and thick sections stained with toulidine blue were used for light microscopic identification of islets and other structures of interest. After staining with uranyl acetate and lead citrate the sections were examined in a Siemens Elmiscope $1 \mathrm{~A}$ and/or 101 .

\section{Results}

\section{Obesity}

The frequency of obese animals in the colony was about 10 per cent. Obesity developed in both sexes but there was a male preponderance in a ratio of about $8: 2$. Gerbils with obvious external signs of obesity weighed more than $80-90 \mathrm{~g}$ and weights up to $140 \mathrm{~g}$ were recorded. The weight of the non-obese controls did not exceed $80 \mathrm{~g}$. The first signs of obesity appeared when the animals were $4-28$ months old, with a mean age of 9 months. The obesity was either transitory or permanent. In the former case the duration of the obese state varied from about 1 month to 10 months. The data obtained so far do not suggest any familial accumulation of obese animals. Apart from obesity no other clinical signs of any disease were recorded.

\section{Urine and Blood Glucose, Glucose Tolerance, and Serum Insulin}

Glucosuria was found at one or more observation times in 14 of the obese gerbils. Three of them were permanently glucosuric from about 1--4 months after the development of obesity ("diabetic animals"), whereas the rest possessed transitory or intermittent glucosuria. The diabetic animals were 2 males and 1 female; 5, 7 and 11 months old at the first appearance of glucosuria. No glucosuria was observed in the nonobese animals.

The mean fasting blood glucose level of the nonobese animals was $83 \pm 4 \mathrm{mg} / 100 \mathrm{ml}$ ( \pm S.E.M.). The approximate limit values for normo-glycemia were calculated to be 40 and $125 \mathrm{mg} / 100 \mathrm{mI}$. All the blood glucose values in the non-obese animals fell within the normal range.

The mean fasting blood glucose level of the obese animals was $105 \pm 5 \mathrm{mg} / 100 \mathrm{ml}( \pm \mathrm{S}$. E.M.). Thus, although the mean fasting blood glucose level in the obese animals fell within the normal range, it was higher than in the controls. Hyperglycemia was recorded at one or more observation times in 15 obese animals. Three of these were permanently hyperglycemic, whereas the others showed transitory or intermittent hyperglycemia. 
The glucose tolerance was decreased in most of the obese gerbils as compared with that of the non-obese ones. The mean values of the glucose tolerance tests performed in the 42 obese and 20 non-obese animals are given in Fig. 1 that is based upon the mean values of the two or more tests performed in each animal.

The present study included only some preliminary determinations of the serum immunoreactive insulin level. As far as can be concluded from these determinations, most obese animals were hyperinsulinemic. The mean value of the obese gerbils was $5.7 \pm 1.9 \mathrm{mug}$ / $\mathrm{ml}$ and that of the non-obese ones $1.1 \pm 0.8 \mathrm{~m} \mu \mathrm{g} / \mathrm{ml}$.

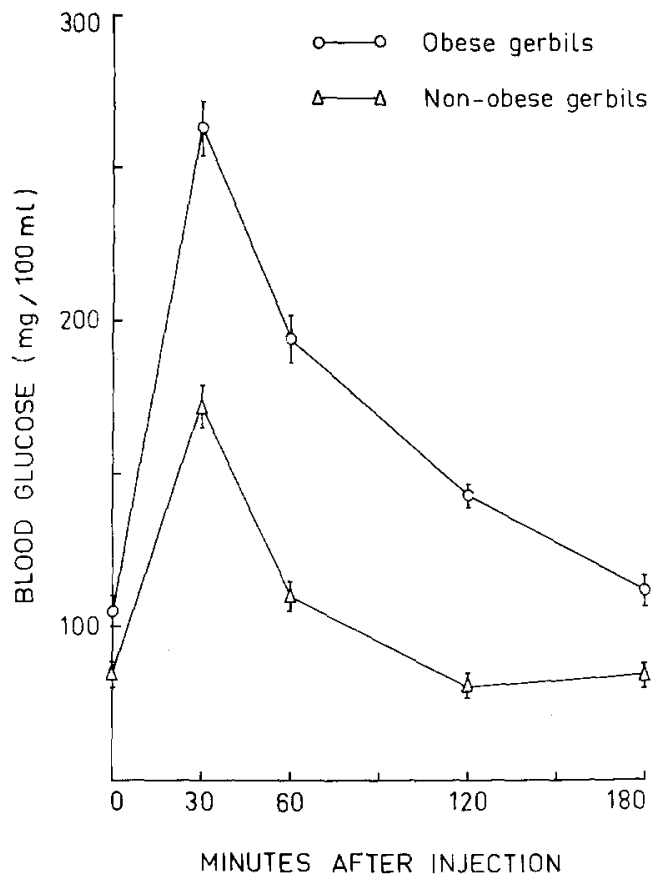

Fig. 1. Glucose tolerance tests (glucose was injected intraperitoneally at a dose of $2 \mathrm{~g} / \mathrm{kg}$ bodyweight) in 42 obese and 20 non-obese Mongolian gerbils. Mean values $\downarrow$ S.E.M.

\section{Light microscopic findings}

The general appearance of the exo- and endocrine portion of the pancreas in the non-obese gerbils was essentially similar to that of other rodent species; $\beta$ - (B), $\alpha_{1^{-}}$(D) and $\alpha_{2^{-}}(\mathrm{A})$ cells were identified.

The endocrine pancreas of the obese gerbils was either similar to that of the non-obese animals, or more often it exhibited signs of hyperplasia of varying degree. In the latter case both the number and size of the islets were increased (Fig. 2) and irregular islets occurred in addition to the ordinary rounded and oval ones. Small buds of islet parenchymal cells were seen on the larger islets and two or more islets occasionally seemed to be fused, sometimes with the appearance of dumb-bell shaped islets (Fig. 3).

There was a rich vascular supply in the hyperplastic islets that mainly were composed of $\beta$-cells with sparse granulation. Only a few $\alpha_{1}$ - and $\alpha_{2}$-cells were seen as a peripheral rim.

Some islets contained a varying amount of large cells without or with very faint cytoplasmic granulation, probably representing degranulated, hypertrophic

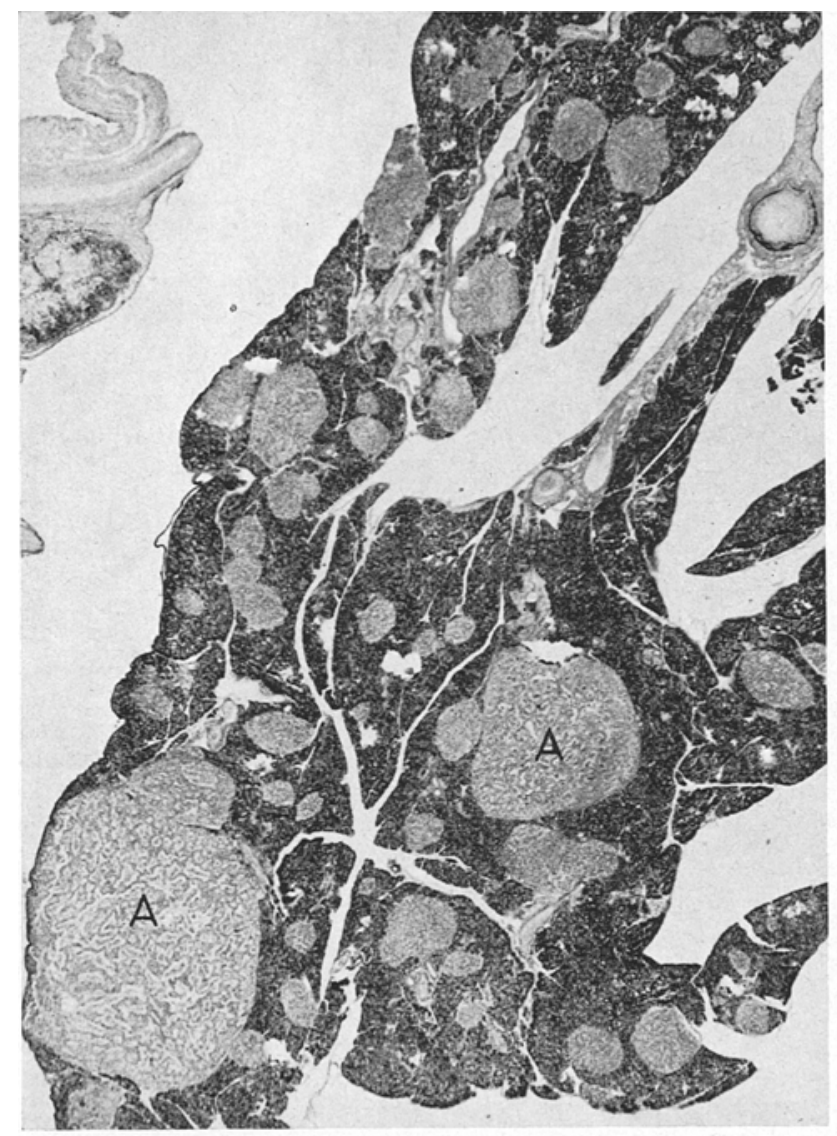

Fig. 2. Transverse section of the body of the pancreas from obese gerbil showing islet hyperplasia with a great num. ber of normal-sized and enlarged islets, some of them seem to be fused. Two adenomatous islets (A) with associated cell buds are also seen. Aldehyde-fuchsin stain. $\times 15$

$\beta$-cells (Fig. 4). These cells occurred both in the central and peripheral portion of the islets. They had one or sometimes two large nuclei that often were peripherally situated and possessed one or two prominent nucleoli (Fig. 5).

Occasional mitotic figures were seen in the $\beta$-cells of hyperplastic islets (Fig. 5). Glycogen accumulation was found in the cytoplasm of the $\beta$-cells, and in dia. betic gerbils there was so-called hydropic degeneration in some islets (Fig. 6). The diabetic animals possessed also pyknosis and signs of cytoplasmic degeneration in a few $\beta$-cells.

Adenomatous giant islets were found in cases with marked islet hyperplasia (Fig. 2). They were surrounded by small, normal-sized islets that often were separated from the adenomatous tissue only by a few strands of collagenous connective tissue (Fig. 7). The 
adenomatous islets exhibited a network of sinusoidal blood vessels between cords of parenchymal cells that were slightly polymorphous and had rounded nuclei with a coarse chromatin pattern and distinct large nucleoli. The tinctorial characteristics of these cells

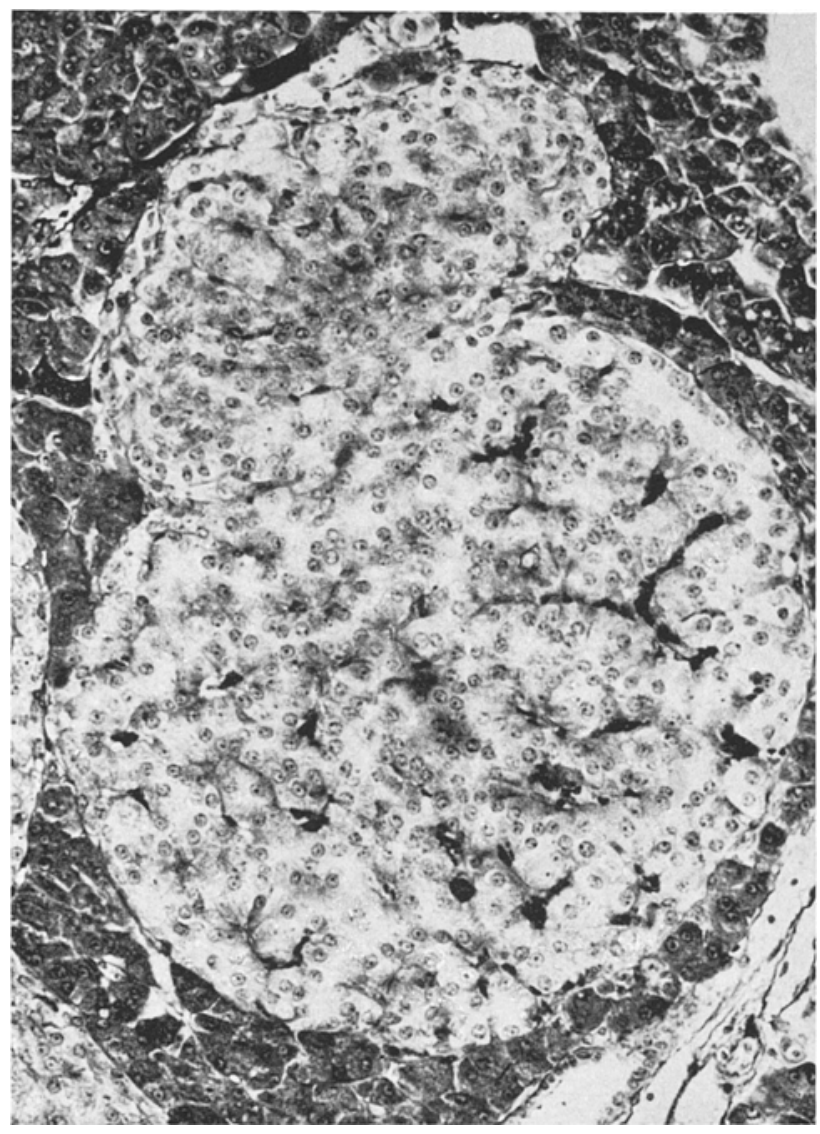

Fig. 3. Islet hyperplasia in obese gerbil. The islet shows a tendency to dumb-bell-shape, rich vascularization, central sparsely granulated $\beta$-cells, and peripheral $\alpha$-cells. Portions of neighboring islets are also seen. Aldehydefuchsin stain. $\times 180$

denoted that they were of $\beta$-type. Scattered cells of $\alpha_{1}-$ and $\alpha_{2}$-type were only infrequently seen.

The exocrine pancreas of the obese animals was normal. Pancreatic ductules were occasionally seen in association with normal-sized or hyperplastic islets. Peripheral nerves and ganglionic cells were seen, without any relationship to the islets.

\section{Electron Microscopic Findings}

The fine structure of the endocrine pancreas of the non-obese gerbils was essentially similar to that of other rodent species. The light microscopic observation of $\beta$ - (B), $\alpha_{1}-(\mathrm{D})$ and $\alpha_{2}-(\mathrm{A})$ cells was confirmed.

As to the obese gerbils, signs of high cellular activity were often found in the animals which light microscopically had normal pancreatic islets. Thus, there

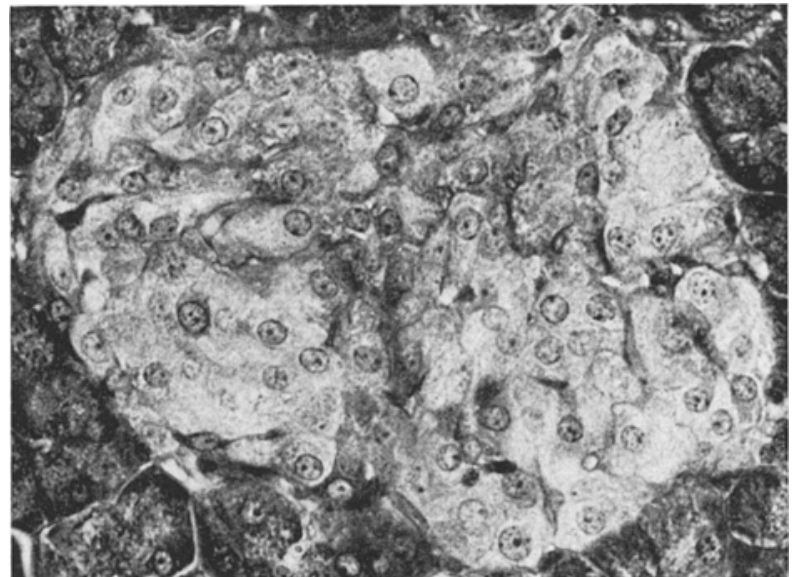

Fig. 4. Pancreas from obese gerbil with islet hyperplasia showing numerous large cells with sparse granulation and often peripherally situated nuclei. Aldehyde-fuchsin stain. $\times 290$

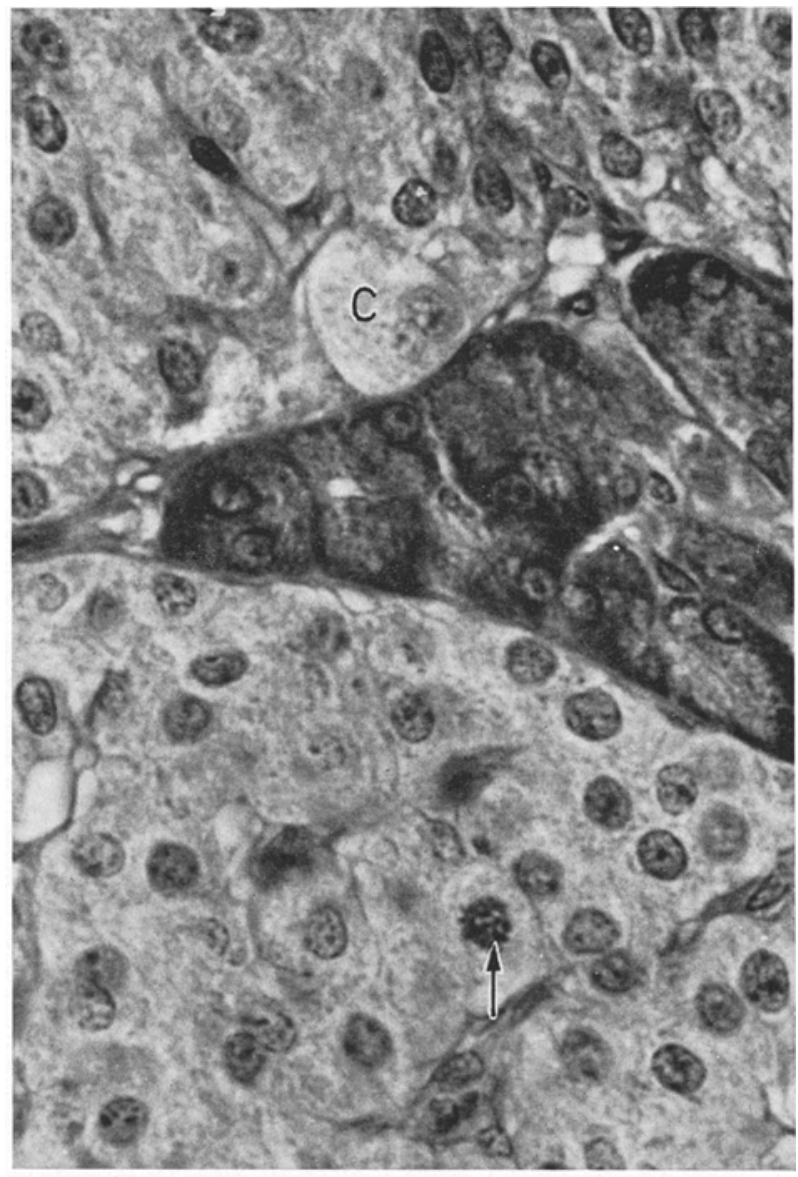

Fig. 5. Portion of two fused hyperplastic islets showing large cells with faint granulation, one of them has two peripheral nuclei (C). One mitotic figure is seen (arrow). Aldehyde-fuchsin stain. $\times 380$

was a well developed Golgi complex (Fig. 8), a prominent rough-surfaced endoplasmic reticulum and a moderate or large amount of mitochondria. The 


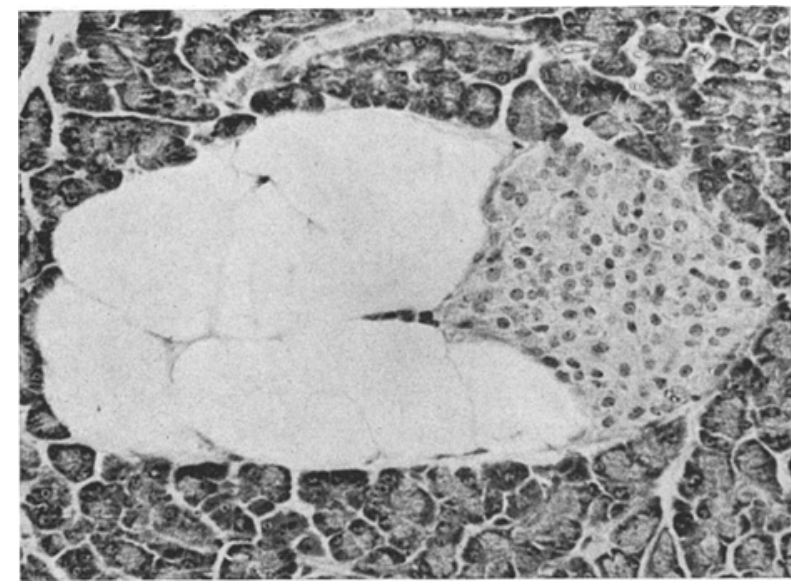

Fig. 6. Islet of diabetic obese gerbil, showing so-called hydropic degeneration. van Gieson's stain. $\times 120$ granules. The cytoplasm of the $\beta$-cells showed varying density and contained numerous free ribosomes and occasional microtubules. Some $\beta$-cells exhibited an abundant amount of mitochondria that often were elongated and curved. The adenomatous islets were composed of cells with a varying number of secretory granules of $\beta$-type.

Other, rather infrequent findings in the $\beta$-cells were large eytoplasmic vacuoles and marked degenerative changes with the appearance of pyknotic nuclei, swollen and distintegrated mitochondria, condensed cytoplasm, and disorganized Golgi complex and endoplasmic reticulum. Lysosomes with incorporated secretory granules could be seen. The degenerative alterations were mainly confined to the diabetic animals.

The cells that light microscopically were large, granule-poor, and interpreted as hypertrophic $\beta$-cells,

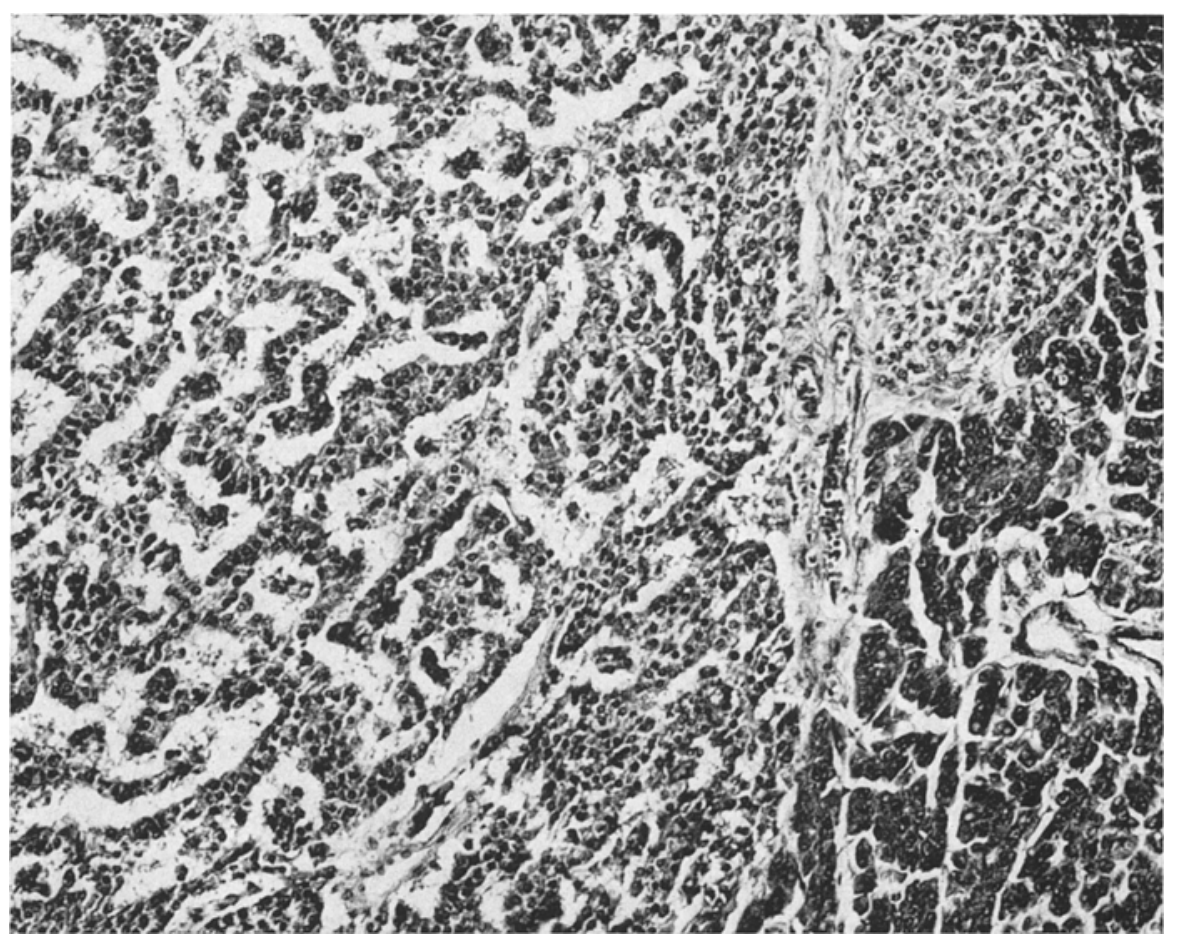

Fig. 7. Portion of adenomatous islet demonstrating cords of parenchymal cells and rich vascular supply. A normalsized islet is separated from the adenomatous one only by a few strands of connective tissue. Aldehyde-fuchsin stain. $\times 90$

number of secretory granules in these cells varied. Signs of emiocytosis were occasionally observed.

The obese gerbils with light microscopic evidence of islet hyperplasia, were ultrastructurally found to possess $\beta$-cells with similar signs of high cellular activity as mentioned above. The Golgi complex often contained numerous prosecretory granule eores (Fig. 9). The number of secretory granules in these cells varied; often they were degranulated. A variation in granule size was also observed; some $\beta$-cells possessed rather large granules, whereas others had numerous small were ultrastructurally found to have low cytoplasmic electron density, a prominent Golgi complex and endoplasmic reticulum, and a moderate amount of free ribosomes, smooth-surfaced vesicles and mitochondria. Only a few secretory granules of $\beta$-type were found in these cells (Fig. 10).

Some mitochondria of undamaged $\beta$-cells possessed longitudinal cristae and parallel, electron dense, rodshaped structures (Fig. 11).

The $\alpha_{1}$-cells that were characterized by numerous secretory granules of low density, were unaffected. 
Some $\alpha_{2}$-cells contained lipoid bodies and Iysosomes with incorporated secretory granules. Lipoid bodies occurred also in large amount in the cytoplasm of some $\beta$-cells.

Dilated intercellular spaces and microvilli on the surrounding $\beta$-cell membranes were found in hyperplastic islets. In the dilated spaces cilia could be seen, some of them were swollen and contained vesicular
- the Chinese hamster [2] - obesity is a component of the syndrome. Obesity, with or without associated hyperglycemia, often develops when the animals are transferred from their wild environment to laboratories. This is most often the case when their normal habitat is desert or semi-desert regions [17]. Hereditary factors may be involved in the development of obesity in laboratory rodents. Furthermore, dietary factors may

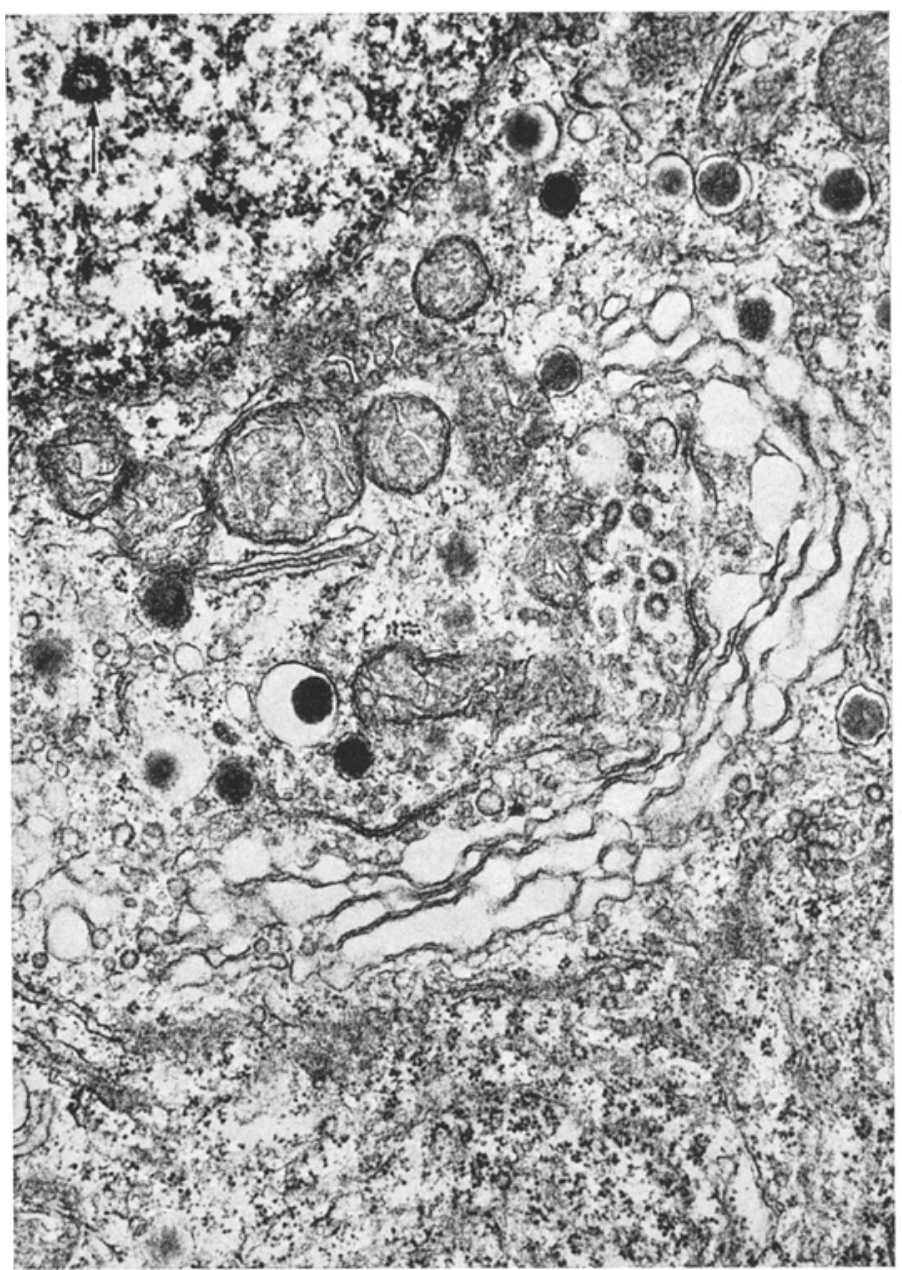

Fig. 8. Electron micrograph of $\beta$-cell from obese gerbil showing a well developed Golgi complex with an enclosed granule core, secretory granules, mitochondria, and a so-called nuclear body (arrow). $\times 19000$

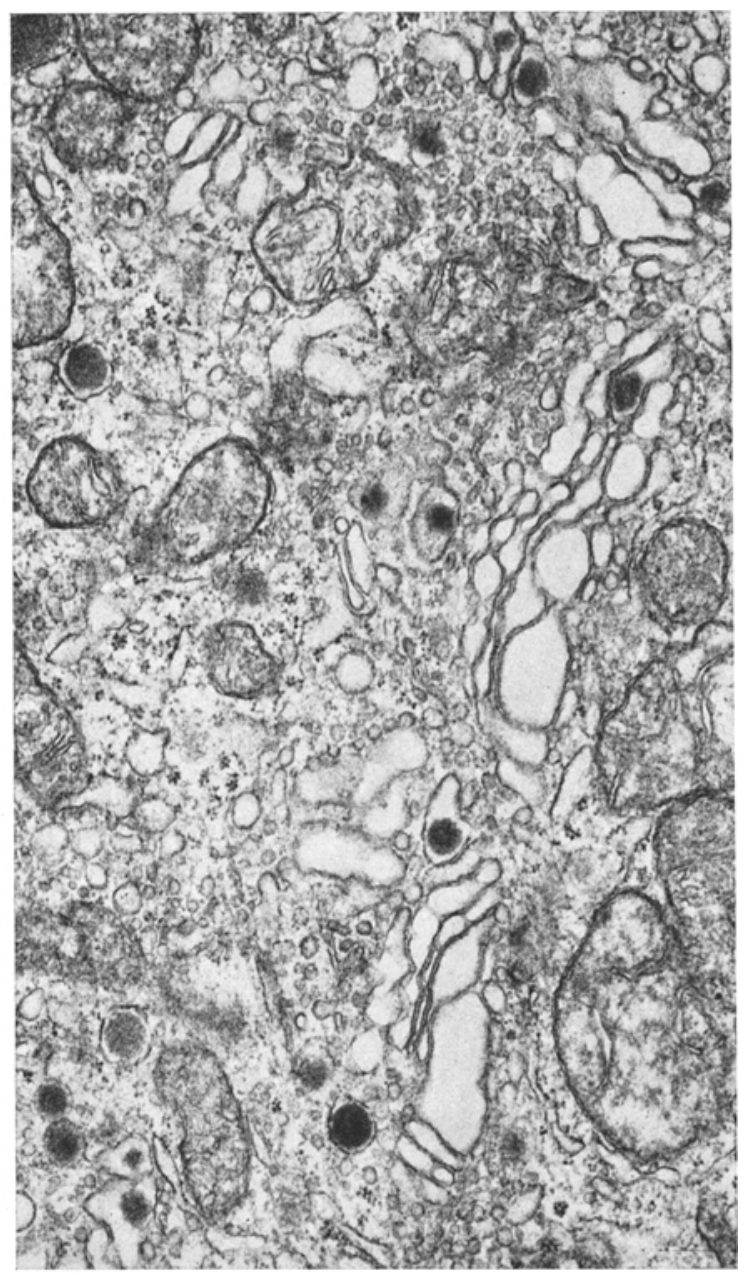

Fig. 9. Prominent $\beta$-cell Golgi complex containing numerous prosecretory granules. $\times 13500$ particles (Fig. 12). Intranuclear rods and so-called nuclear bodies (Fig. 8) were seen in the $\beta$-cells. The cilia and nuclear inclusions were similar to those seen in non-obese animals $[3,4]$.

\section{Discussion}

Syndromes associated with hyperglycemia and/or obesity are known to occur in about a dozen different kind of laboratory rodents [16]. In all but one of these play a role, e.g. in sandrats [9, 10], KK-mice [13], and Wellesley hybrid mice [8]. Desert regions are the natural habitat of the Mongolian gerbil. It belongs to the same subfamily (Gerbillinae) as the sandrat. In this laboratory, the gerbils are maintained on a laboratory diet which has a composition and caloric value apparently quite different from that of the diet available in the regions from which the animals originally came. It is believed that the altered environmental and dietary conditions brought about by the transfer of the gerbils to the laboratory are the most important 


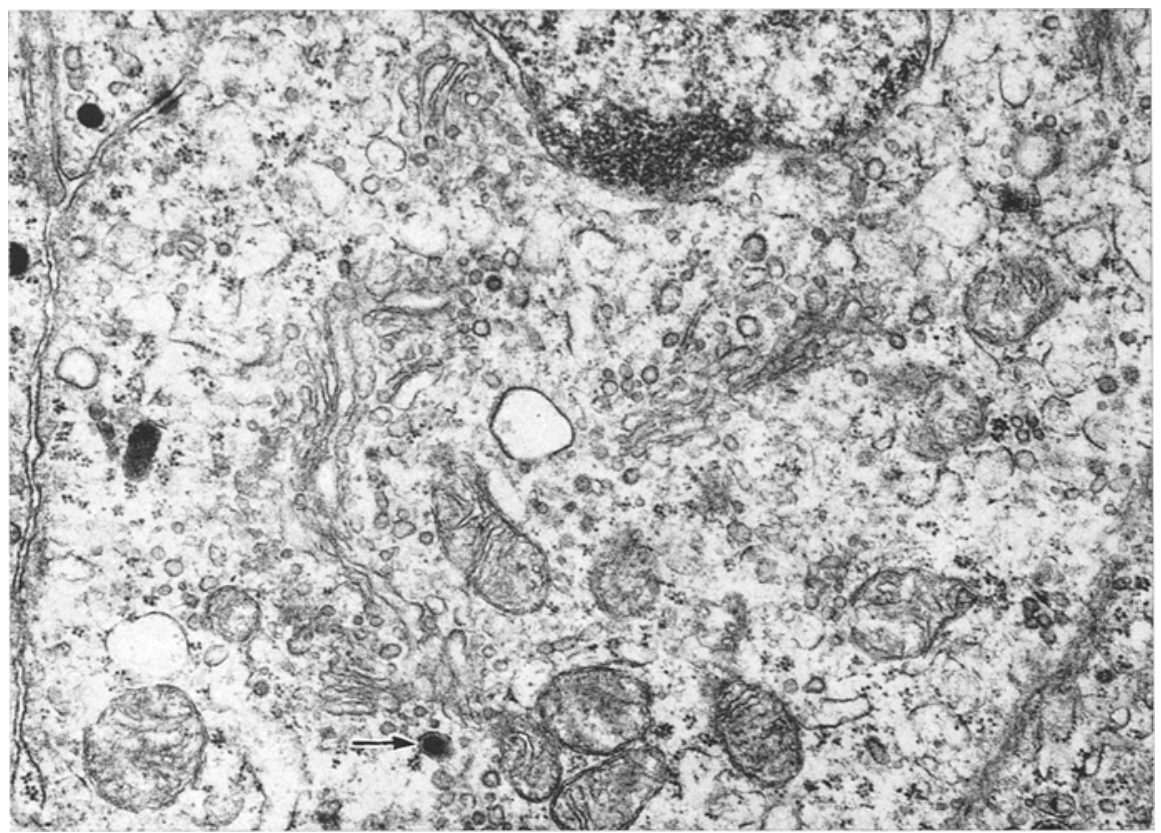

Fig. 10. Portion of large, degranulated $\beta$-cell showing low cytoplasmic electron density, Golgi complex, mitochondria and one secretory granule (arrow) $\times 10000$

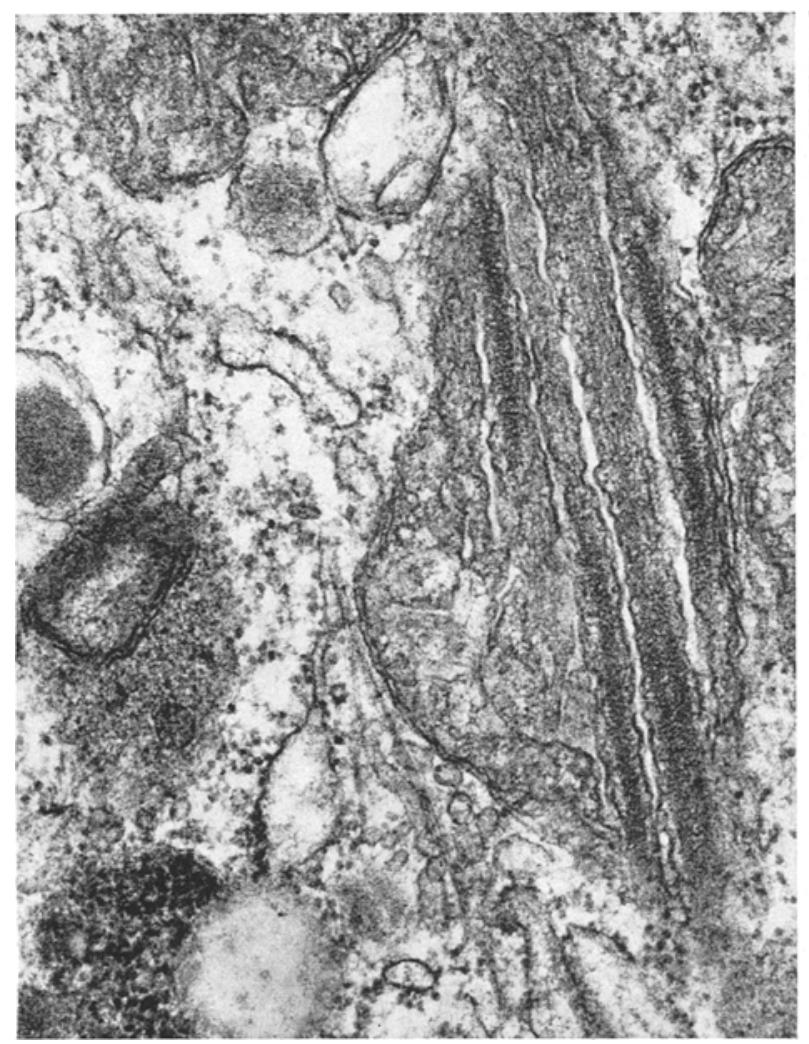

Fig. 11. $\beta$-cell mitochondrion possessing longitudinal cristae and parallel electron dense, rod-shaped structures. $\times 28000$

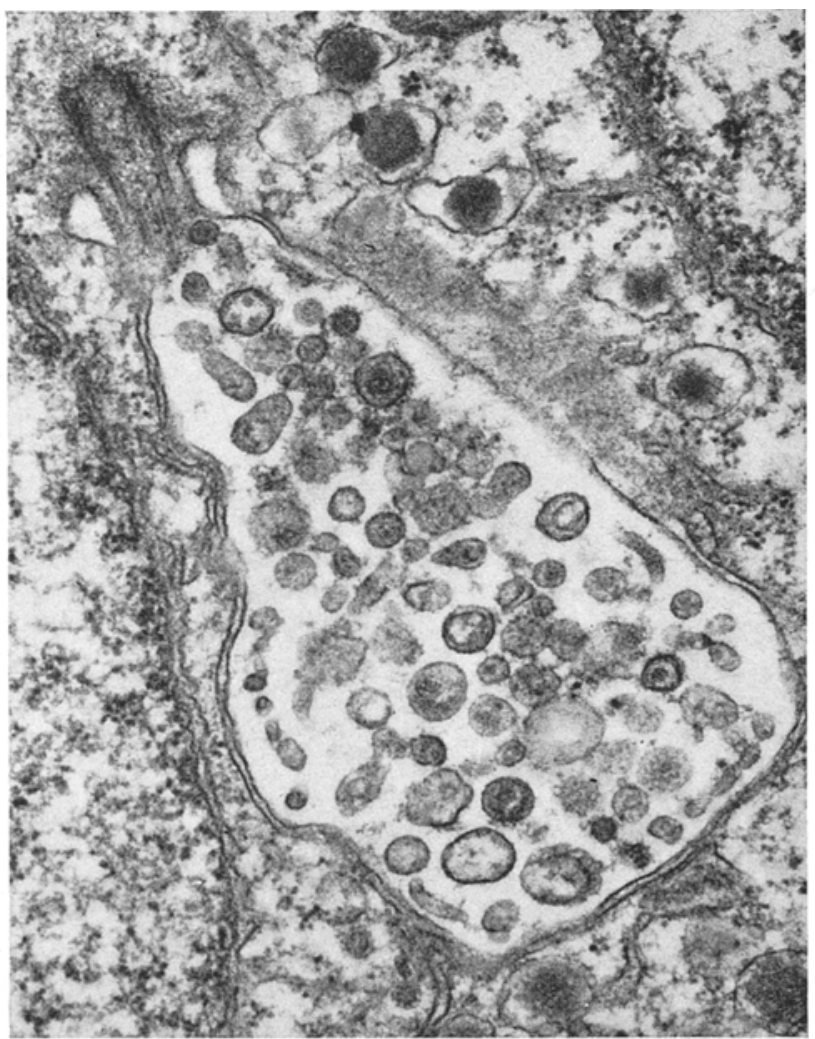

Fig. 12. Cilium extending from a $\beta$-cell into a dilated intercellular space. Vesicular particles of varying size and shape are enclosed within the dilated ciliary membranes, $\times 26000$ 
factors in the development of obesity in some of these animals. However, inasmuch as they have been inbred, genetic factors might also have some pathogenetic significance.

Obese-hyperglycemic syndroms in laboratory rodents may be of transitory nature. In obese mice Westman [20] found a significantly higher body-weight already at an age of 26 days, after which time the weight gain continued until the animals were about $5-6$ months old. The obesity in the Mongolian gerbil was in some cases transitory. No clear association of the symptoms to the age was found in the gerbils although most of them were young when they began to develop obesity.

Many rodent species in which obesity develops, do also exhibit hyperglycemia and glucosuria. However, normo-glycemia may occur in the sandrat [9] although the glucose tolerance is decreased. In the Mongolian gerbils there were only a few cases of hyperglycemia and glucosuria, whereas the glucose tolerance was decreased in most obese animals. It is, however, worth to note that the mean level of fasting blood glucose was higher in the obese than in the lean animals. Using an undefined method, Mays [14] found a blood glucose level of approximately $94 \pm 25 \mathrm{mg} / 100 \mathrm{mI}$ in normal Mongolian gerbils.

There are numerous reports on hyperinsulinemia and altered peripheral sensitivity to insulin in obese animals, e.g. in obese hyperglycemic mice [12] and $\mathrm{KK}$-mice [7]. In the sandrat there is an initial increase and a subsequent fall of the serum insulin level attributed to pancreatic exhaustion [15]. Obesity decreases the insulin sensitivity of adipose tissue also in Wellesley hybrid mice [6] and human subjects [18]. Preliminary studies denoted that hyperinsulinemia occurs also in obese gerbils.

The $\beta$-cells of the obese gerbils were often sparsely granulated denoting an intense and rapid release of insulin with no or only a slight tendency to hormone storage in secretory granules. Consistent with this are the presence of secretory granules in the Golgi regions and signs of high cellular activity, and the occurrence of seemingly hypertrophic $\beta$-cells. The mitochondrial rod-shaped structures occurring in some $\beta$-cells beared some resemblance to the tubular bodies previously observed in mitochondria of $\beta$-cells in mice [5]. Their significance remains doubtful.

In most obese gerbils there were signs of hyperplasia of the endocrine pancreas, sometimes of considerable degree. The finding of mitotic figures in the $\beta$-cells denote that the hyperplasia, at least partly, was achieved by division of mature $\beta$-cells. The occasionally observed association between ductules and islets might indicate a new formation of endocrine cells also from ductules.

Adenomatous islets have occasionally been observed in alloxan-treated Chinese hamsters [1] and streptozotocin-treated rats [19]. The presence of such islets in the pancreas of obese gerbils is believed to be a result of the high hyperplastic activity of the endocrine pancreas. The occurrence in these islets of granulated $\beta$-cells and a rich vascular supply denotes that they may be hormonally active and not merely represent a neoplastic "degeneration".

The results indicate that the Mongolian gerbil has a good capacity for new formation of islet cells and that the hyperplasia of the endocrine pancreas often is sufficient to establish an adequate insulin production for the maintenance of normo-glycemia in obese gerbils. Only in a few cases does the functional capacity of the pancreatic islets of obese animals seem to be insufficient to meet the increased demands associated with obesity, in which cases glucosuria and hyperglycemia occur (diabetic animals). Marked degenerative changes of the $\beta$-cells were observed only in diabetic animals suggesting that their $\beta$-cells are exhausted.

\section{References}

1. Boquist, L.: Alloxan administration in the Chinese hamster. I. Blood glucose variations, glucose tolerance, and light microscopical changes in pancreatic islets and other tissues. Virch. Arch. Abt. B Zellpath. 1, $157-168(1968)$.

2. - Pancreatic islet morphology in diabetic Chinese hamsters. A light and electron microscopic study. Acta Path. Microbiol.Scand. 75, 399-414 (1969).

3. - Cilia and vesicular particles in the endocrine pancreas of the Mongolian gerbil. J. Cell. Biol. 45, $532-541(1970)$.

4. - Some peculiar fine structures in the pancreatic islets of diabetic and non-diabetic rodents. Acta Diabetol. Lat. 7, 590-615 (1970).

5. - Tubular cytoplasmic bodies in pancreatic islet B-cells of mice. $Z$. Zellforsch. 106, $69-78$ (1970).

6. Cahill, G.F., Jr., Jones, E.E., Lauris, V., Steinke, J., Soeldner, J.S.: Studies on experimental diabetes in Wellesley hybrid mouse. II. Serum insulin levels and response of peripheral tissues. Diabetologia 3, 171 174 (1967).

7. Dulin, W.E., Wyse, B.M.: Diabetes in the KK mouse. Diabetologia 6, 317-323 (1970).

8. Gleason, R.E., Lauris, V., Soeldner, J.S.: Studies on experimental diabetes in Wellesley hybrid mouse. III. Dietary effects and similar changes in a commercial Swiss-Hauschka strain. Diabetologia 3, 175-178 (1967).

9. Hackel, D.B., Lebovitz, H.E., Frohman, L.A., Nikat, E., Schmidt-Nielsen, K.: Effect of caloric restriction on the glucose tolerance and plasma insulin of the sandrat. Metabolism 16, 1133-1139 (1967).

10. Haines, H., Hackel, D.B., Schmidt-Nielsen, K.: Experimental diabetes mellitus induced by diet in the sand rat. Amer. J. Physiol. 208, 297-300 (1965),

11. Hales, C.M., Randle, P.J.: Immunoassay of insulin with insulin-antibody precipitate. Biochem. J. 88, $137-146$ (1963).

12. Hellerström, C., Westman, s., Herbai, G., Petersson, B., Westman, J., Borglund, E., Östensson, C.G.: Pathogenetic aspects of the obese-hyperglycemic syndrome in mice (Genotype obob): II. Extrapancreatic factors. Diabetologia 6, 284-291 (1970).

13. Matsuo, T., Shino, A., Iwatsuka, H., Suzuoki, Z.: Induction of overt diabetes in KK mice by dietary means. Endocrinol. Japon. 17, 477-488 (1970).

14. Mays, A., Jr.: Baseline hematological and blood biochemical parameters of the Mongolian gerbil 
(Meriones unguiculatus). Lab. Animal Care 19, 838842 (1969).

15. Miki, E., Like, A.A., Soeldner, J.S., Steinke, J., Cahill, G.F., Jr.: Acute ketotic-type diabetic syndrome in sandrats (Psammomys obesus) with special reference to the pancreas. Metabolism 15, 749-760 (1966).

16. Renold, A. E.: Spontaneous diabetes and/or obesity in laboratory rodents. In: Advances in Metabolic Disorders, Levine, R., Luft, R., Eds. Vol. III, pp. 49-84. New York and London: Academic Press 1968.

17. - Burr, I.: The pathogenesis of diabetes mellitus. Possible usefulness of spontaneous hyperglycemic syndromes in animals. Calif. Med. 112, 23-34 (1970).

18. Salans, L.B., Knittle, J.L., Hirsch, J.: 'The role of adipose cell size and adipose tissue insulin sensitivity in the carbohydrate intolerance of human obesity. J. clin. Invest. 47, 153-165 (1968).

19. Steiner, H., Oelz, O., Zahnd, G., Froesch, E. R. Studies on islet cell regeneration, hyperplasia and intrainsular cellular interrelations in long lasting streptozotocin diabetes in rats. Diabetologia 6, 558$564(1970)$.

20. Westman, S.: The development and manifestations of the obese-hyperglycemic syndrome in mice. Abstracts of Uppsala Dissertations in Medicine No. 49 (1968).

Lennart Boquist, M.D.

Institute of Pathology

University of Umeå

S-901 87 Umeå, Sweden 